\title{
Casein Interactions Studied by the Surface Plasmon Resonance Technique
}

\author{
S. Marchesseau, ${ }^{\star}$ J-C. Mani, $\neq$ P. Martineau, † F. Roquet, $†$ J-L. Cuq, ${ }^{\star}$ and M. Pugnière† \\ *Laboratoire de Génie Biologique et Sciences des Aliments, \\ Université Montpellier II, 34095 Montpellier Cedex 5, France \\ †CNRS UMR 5094, Institut de Biotechnologie et Pharmacologie, \\ Faculté de Pharmacie, 34093 Montpellier Cedex 5, France \\ $\ddagger$ The paper is dedicated to the memory of Dr. Jean-Claude Mani
}

\section{ABSTRACT}

Surface plasmon resonance technique was investigated for the first time to study the apparent hydrophobicity and association properties of the major bovine caseins: $\alpha_{\mathrm{s}}-\left(\alpha_{\mathrm{s} 1^{-}}\right.$and $\alpha_{\mathrm{s} 2^{-}}$caseins in a $4: 1$ proportion), $\beta$-, and $\kappa$-caseins. The apparent hydrophobicities of the caseins were evaluated by a new method based on the binding level of casein on a hydrophobic sensor chip, and kinetic and equilibrium affinity constants were determined for the following casein interactions: $\alpha_{\mathrm{s}} / \alpha_{\mathrm{s}}, \alpha_{\mathrm{s}} /$ $\beta, \alpha_{\mathrm{s}} / \kappa, \beta / \beta$, and $\beta / \kappa$, using a sensor chip modified with covalent immobilized caseins. The study by surface plasmon resonance technology of these casein interactions under different conditions $(\mathrm{pH}$, ionic strength, calcium concentration, chemical modification) demonstrated that, at neutral $\mathrm{pH}$, electrostatic repulsive forces play an important role since an increase in ionic strength of the medium resulted in a stronger interaction. When charge repulsions were reduced by either acidification, increase in ionic strength, or dephosphorylation, casein interactions were reinforced, presumably due to weak attractive forces. Moreover, in this molecular model, we showed that addition of calcium greatly increased the binding response between the most phosphorylated caseins and that the added calcium $(2 \mathrm{mM})$ participated directly in the formation of bridges between the phosphate groups of the casein molecules.

(Key words: bovine casein, casein interaction, surface plasmon resonance, BIACORE)

Abbreviation key: $\mathbf{k}_{\mathbf{a}}=$ association rate constant; $\mathbf{k}_{\mathbf{d}}$ $=$ dissociation rate constant; $\mathbf{K}_{\mathbf{D}}=$ equilibrium dissociation constant; $\mathbf{P 2 0}=$ polyoxyethylenesorbitan; $\mathbf{R u}=$ resonance unit; $\mathbf{S P R}=$ surface plasmon resonance.

Received October 12, 2001.

Accepted January 25, 2002.

Corresponding author: M. Pugnière; e-mail: martine.pugniere@ ibph.pharma.univ-montp.fr.

\section{INTRODUCTION}

Caseins, which account for 76 to $86 \%$ of the total milk protein (30 to $35 \mathrm{~g} / \mathrm{L}$ ), are heterogeneous proteins represented by four principal proteins: $\alpha_{\mathrm{s} 1^{-}}, \alpha_{\mathrm{s} 2^{-}}, \beta-$, and $\kappa$-casein in the approximate proportion of $38,10,36$, and 13\% (Davies and Law, 1980). Additional heterogeneity arises from post-translational processing such as phosphorylation, glycosylation (only $\kappa$-casein), and limited proteolysis [yielding $\gamma$-caseins and proteose-peptones (3\%) during the proteolytic action of plasmin on $\beta$-caseins] (Swaisgood, 1992). All the caseins are relatively small phosphoproteins (19 to $25 \mathrm{kDa}$ ) and strongly hydrophobic in the rank of $\beta->\kappa^{-}>\alpha_{\mathrm{s} 1^{-}}>\alpha_{\mathrm{s} 2}$-caseins (Fox, 1989). The primary sequence indicates that the hydrophobic and polar or charged residus are not uniformly distributed (Swaisgood, 1992). The caseins have a particular amphiphilic nature arising from a separation between hydrophobic clusters and negativelycharged regions along the peptide chain, which explains the differences in their association properties. Caseins are not present in milk as individual molecular structures but rather as large protein complexes that also incorporate milk salts, particularly calcium salts. Self association of bovine caseins (Schmidt, 1970; Berry and Creamer, 1975; Buchheim and Schmidt, 1979; Snoeren et al., 1980; Slattery et al., 1989) and associations between different casein species (Payens, 1966; Schmidt, 1982; Rollema, 1992; Horne, 1998; De Kruif, 1999) have been investigated extensively because of their innate importance in the structure of the casein micelle particles (Schmidt and Payens, 1976) and in the nature of the forces maintaining their integrity. Casein molecules present also a strong affinity for bivalent and trivalent cations, attributable mainly to phosphoseryl residues (Baumy et al., 1989; Gaucheron et al., 1997). This property is important for the micellar integrity of caseins, which is greatly dependent on the presence of colloidal calcium phosphate (Walstra, 1990).

Casein interactions have been studied by sedimentation equilibrium patterns obtained by ultracentrifugation (Berry and Creamer, 1975; Buchheim and Schmidt, 
1979) and by small-angle neutron scattering and light scattering experiments (Thurn et al., 1987). In the present study, the mechanism of casein interactions has been explored for the first time by surface plasmon resonance (SPR) technology. This new technology called biomolecular interaction analysis (BIA) is a labelfree technology that monitors in real time molecular binding processes on the surface of a specially prepared biosensor chip. In this paper, we chose to analyze the interactions between three major categories of caseins, namely $\alpha_{\mathrm{s} 1^{-}}$and $\alpha_{\mathrm{s} 2^{-}}$caseins (the highly phosphorylated caseins), $\beta$-casein (the most hydrophobic casein), and $\kappa$-casein (the glycosylated casein), on a hydrophobic surface (HPA sensor chip) or bound to a particular casein immobilized on a hydrophilic sensor chip (CM5). The importance of various intermolecular binding forces and the influence of different parameters such as $\mathrm{pH}$, ionic strength, calcium concentration, and chemical modification were evaluated to provide information on the mechanisms involved in the association of these complex molecules.

\section{MATERIALS AND METHODS}

\section{Materials}

The molecular interactions between the different caseins were investigated by surface plasmon resonance (SPR) using BIACORE 2000 (Biacore AB, Uppsala, Sweden). Commercial purified bovine caseins $\left(\alpha_{\mathrm{s}}, \beta, \kappa\right.$, and dephosphorylated $\alpha_{\mathrm{s}}$ ) were purchased from Sigma Chemical Co., St. Louis, MO. CM5 and HPA sensor chips, N-hydroxysuccinimide (NHS), N-ethyl-N'-(dimethylaminopropyl)-carbodiimide (EDC), ethanolamine hydrochloride (1 $M), \mathrm{pH} 8.5$, and HBS buffer (10 $\mathrm{m} M$ HEPES buffer at $\mathrm{pH} 7.4$ containing $150 \mathrm{~m} M \mathrm{NaCl}$, $3 \mathrm{~m} M$ EDTA, and $0.005 \%$ of the nonionic surfactant polyoxyethylenesorbitan (P20) were obtained from Biacore AB. All other reagents were of analytical grade.

\section{Gel Filtration Experiments}

All experiments were performed on an ÄKTA explorer system using a Superdex 75 HR10/30 column (Amersham-Pharmacia, Inc.). The column was equilibrated at a flow rate of $0.5 \mathrm{ml} / \mathrm{min}$ with various buffers as described in the figure legend and at a temperature of either 4 or $25^{\circ} \mathrm{C}$. Purified proteins $(0.1 \mathrm{ml})$ were injected at a concentration of $0.1 \mathrm{mg} / \mathrm{ml}$ and detected by following the absorbance at $280 \mathrm{~nm}$. The column was calibrated using a mixture of bovine serum albumin $\left(\mathrm{M}_{\mathrm{t}}=66 \mathrm{kDa}\right.$, Stokes radius $\left.=35.5 \AA\right)$, ovalbumin $(45$ $\mathrm{kDa}, 30.5 \AA)$, chymotrypsinogen A (25 kDa, $20.9 \AA)$, and ribonuclease A (13.7 kDa, $16.4 \AA)$.

\section{SPR Detection Principle}

Surface plasmon resonance is an optical phenomenon which is sensitive to changes in the optical properties of the medium close to the sensor surface. The detection system of the SPR monitor essentially consists of a monochromatic and polarized light source, a glass prism, a thin metal film in contact with the base of the prism, and a photodetector. Light traveling through an optically denser medium, e.g., a glass prism, is totally reflected back into the prism when reaching the interface to an optically less dense medium, e.g., buffer, provided that the angle of incidence is larger than the critical angle. This is known as total internal reflection. Although the light is totally reflected, a component of this incident light momentum called the evanescent wave penetrates a distance of the order of one wavelength into the buffer. The evanescent wave may be used to excite molecules close to the interface. If, however, the light is monochromatic and $p$-polarized and the interface between the media is coated with a thin metal film, the evanescent wave under certain conditions will interact with free-oscillating electrons (plasmons) in the metal thin surface. When SPR occurs, light energy is lost to the metal film and the reflected light intensity is, thus, decreased. The resonance phenomenon will only occur for light incident at a sharply defined angle which, when all else is kept constant, is dependent of the refractive index of the buffer close to the surface. Changes of the refractive index can be followed by continuous monitoring of the resonance angle (Jönsson et al., 1991).

The BIACORE detects changes in refractive index of the solution close to the surface of the sensor chip. To perform interaction analysis, one reactant (the ligand) is immobilized in a dextran matrix on the sensor chip. The sample containing the other reactant (the analyte) is injected over the CM5 surface in a controlled flow. Any change in the surface concentration resulting from the interaction is detected as an SPR signal, expressed in resonance units $(\mathbf{R u})$. One Ru corresponds to approximately $1 \mathrm{pg} / \mathrm{mm}^{2}$ of protein. The continuous display of $\mathrm{Ru}$ as a function of time gives a plot called a sensorgram, which provides a complete record of the progress of association and dissociation between the two interactants. After each analysis, the surface can be regenerated using an appropriate eluant solution that does not affect the immobilized ligand.

\section{Adsorption on the HPA Sensor Chip}

The HPA sensor chip is a flat hydrophobic gold surface covered with closely packed C14-alkanethiol molecules. The HPA chip was cleaned by an injection of octyl D-glucoside (10 min, $10 \mu \mathrm{l} / \mathrm{min}, 40 \mathrm{mM}$ ). Caseins (15 
$\mathrm{ml}, 10 \mu \mathrm{l} / \mathrm{min}, 8 \mu M$ ) were injected immediately after cleaning. After a dissociation time of $600 \mathrm{~s}$, the surface was regenerated with octyl D-glucoside (10 min, $10 \mu \mathrm{l} /$ $\min , 40 \mathrm{~m} M$ ). The running buffer used for all experiments was HBS.

\section{Covalent Immobilization of Casein on CM5 Sensor Chip}

Covalent immobilization of casein to the CM5 (carboxymethyl dextran $500 \mathrm{kDa}$ ) sensor chip was carried out using the standard amine coupling procedure (Pharmacia Biosensor, 1994) at one $\mathrm{pH}$ unit under the protein $\mathrm{p} I$, in acetate buffer $(10 \mathrm{~m} M)$. Each casein $\left(\alpha_{\mathrm{s}}, \beta\right.$, and $\kappa)$ was independently immobilized at a low level to limit mass transport and rebinding on the measuring flowcell. The fourth flowcell did not contain immobilized casein and was taken as a control. Signals obtained from the control flowcell were subtracted from those of the other flowcells to correct the response for nonspecific binding.

\section{Casein/Casein Interaction Analysis}

SPR analysis allows the visualization in real time of the biomolecular interactions of a flowing analyte with an immobilized ligand, without the need to label the interacting partners. The response, measured in resonance unit $(\mathrm{Ru})$, is a direct indication of the amount of bound analyte. The running and sample buffers were $10 \mathrm{~m} M$ HEPES, $\mathrm{pH}$ 7.4, containing $150 \mathrm{~m} M \mathrm{NaCl}$, except for special buffer compositions indicated in the figure legends. All buffers were filtered and degassed. Temperature was maintained at $25^{\circ} \mathrm{C}$. Different concentrations of the caseins were tested, but the results are given for the concentration of $4 \mu M$. The analyte was injected ( $300 \mathrm{~s}, 10 \mu \mathrm{l} / \mathrm{min})$, followed by a dissociation phase $(600 \mathrm{~s})$ in running buffer and a regeneration step $(120 \mathrm{~s})$ with $\mathrm{HCl}(0.1 M)$. The binding levels were measured in all cases $10 \mathrm{~s}$ after the end of injection in order to avoid error due to differences in refractive index between the sample and the dissociation running buffer. These association levels (Ru value at $310 \mathrm{~s}$ ) were directly obtained from the sensorgram after subtraction of the background signal recorded for the control flowcell. Each experiment was repeated at least twice. The values for association rate constant $\left(\mathbf{k}_{\mathbf{a}}\right)$, dissociation rate constant $\left(\mathbf{k}_{\mathbf{d}}\right)$, and equilibrium dissociation constant $\left(\mathbf{K}_{\mathbf{D}}\right)$ were obtained from each sensorgram by selecting a 1:1 Langmuir binding model using a global fitting method (Karlsson and Fält, 1997) from the BIAevaluation 3.1 software.

\section{RESULTS}

\section{Multimerization State of Caseins}

To study casein interactions using BIACORE, it is necessary to know the multimerization state of the proteins in the flow. Thus, we compared the retention volume of caseins by gel filtration chromatography in the buffers used for the BIACORE experiments. Casein molecules, because of their poorly structured conformations, behave on gel filtration columns as much larger proteins (Swaisgood, 1992). To take into account their abnormal retention volumes, we calibrated not only the column with globular protein standards (top chromatogram in Figure 1) but also with purified caseins under conditions known to give monomeric caseins in solution.

$\alpha_{\mathrm{s}}$-Caseins at high $\mathrm{pH}(\mathrm{pH}$ 9.3) and low concentration $(0.1 \mathrm{mg} / \mathrm{ml})$ are monomeric (Swaisgood and Timasheff, $1968)$, and their retention volume $(9.9 \mathrm{ml})$ corresponded to a Stokes radius of $32 \AA$ (Figure 1a), in good agreement with values determined by viscometry measurements (Swaisgood, 1992). At neutral pH (pH 7.4), these proteins were mainly monomeric $(70 \%)$ and eluted at a volume of $10.2 \mathrm{ml}$ (Stokes radius of $30 \AA$ ). There was a second pic, representing $30 \%$ of the protein, at a volume $(9.3 \mathrm{ml})$ which might correspond to a dimeric form of $\alpha_{\mathrm{s}}$-caseins (Figure 1a). At pH 7.4 in the presence of $\mathrm{CaCl}_{2}(2 \mathrm{mM})$ and at acidic $\mathrm{pH}(\mathrm{pH} 5.4)$, the proteins were also present as a monomer in solution (Stokes radius of $29 \AA$ and $30 \AA$, respectively; Figure 1a). In most cases, there were also some high molecular weight multimers eluted in the void volume of the column $(>100$ $\mathrm{kDa}$ ). Dephosphorylated $\alpha_{\mathrm{s}}$-caseins were eluted as a monomer (Stokes radius of 28 to $29 \AA$ ), and no dimer was detected at $\mathrm{pH} 7.4$ or at $\mathrm{pH} 5.4$ with the presence of calcium (Figure 1d). There were still, however, some high molecular weight multimers.

At $4^{\circ} \mathrm{C}, \beta$-casein is a monomer and behaves as a protein with a Stokes radius of $37 \AA$ (Andrews et al., 1979). In Figure 1b, $\beta$-casein exhibited a Stokes radius of 39 A under those conditions. At neutral and acidic $\mathrm{pH}$ and at $25^{\circ} \mathrm{C}$ (conditions used for the BIACORE experiments), the $\beta$-casein was essentially monomeric (80 to $90 \%)$ as indicated by the retention volume $(9.4-9.6 \mathrm{ml})$, and the Stokes radius ( 34 to $35 \AA$ ) were comparable to the values obtained at $4^{\circ} \mathrm{C}$ (Figure $1 \mathrm{~b}$ ).

When analyzed by gel filtration, $\kappa$-casein was eluted in the void volume of the column $\left(\mathrm{M}_{\mathrm{t}}>100 \mathrm{kDa}\right)$, even at the lowest concentration tested in this experiment $(0.1 \mathrm{mg} / \mathrm{ml}$; Figure 1c). This demonstrated that the protein was multimeric and that no monomer was present in solution. This result confirmed that of Groves et al. (1992). 


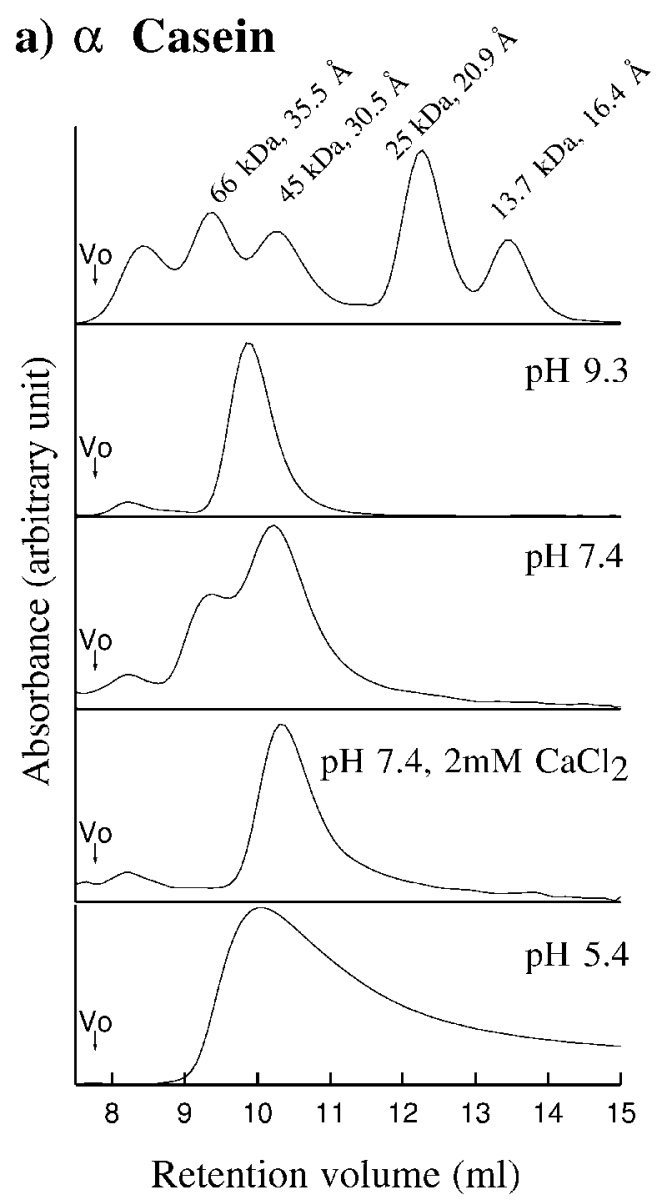

\section{b) $\beta$ Casein}

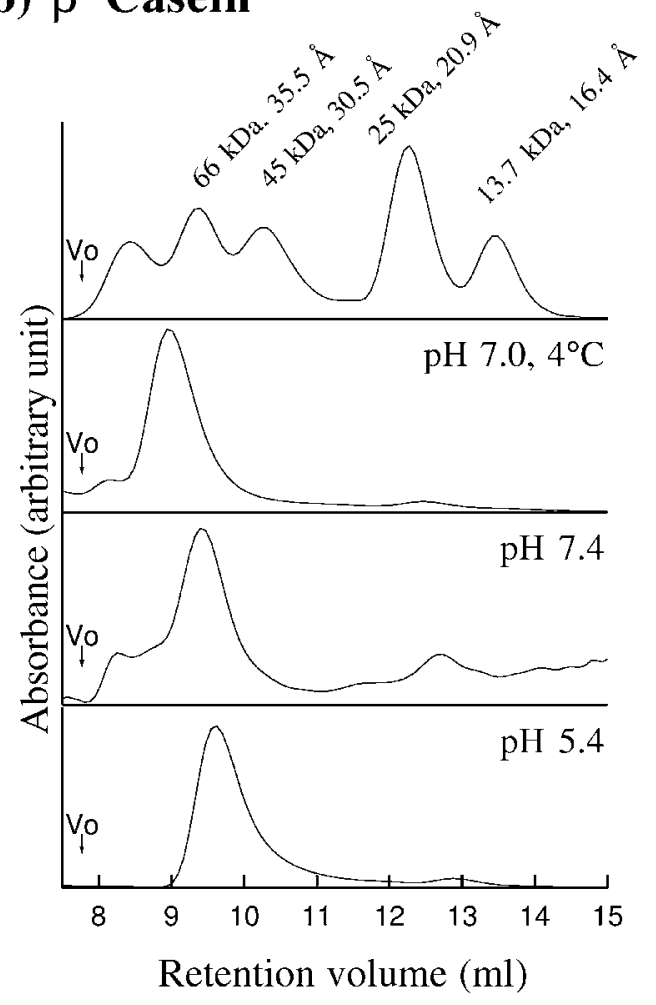

d) Dephosphorylated $\alpha$ casein
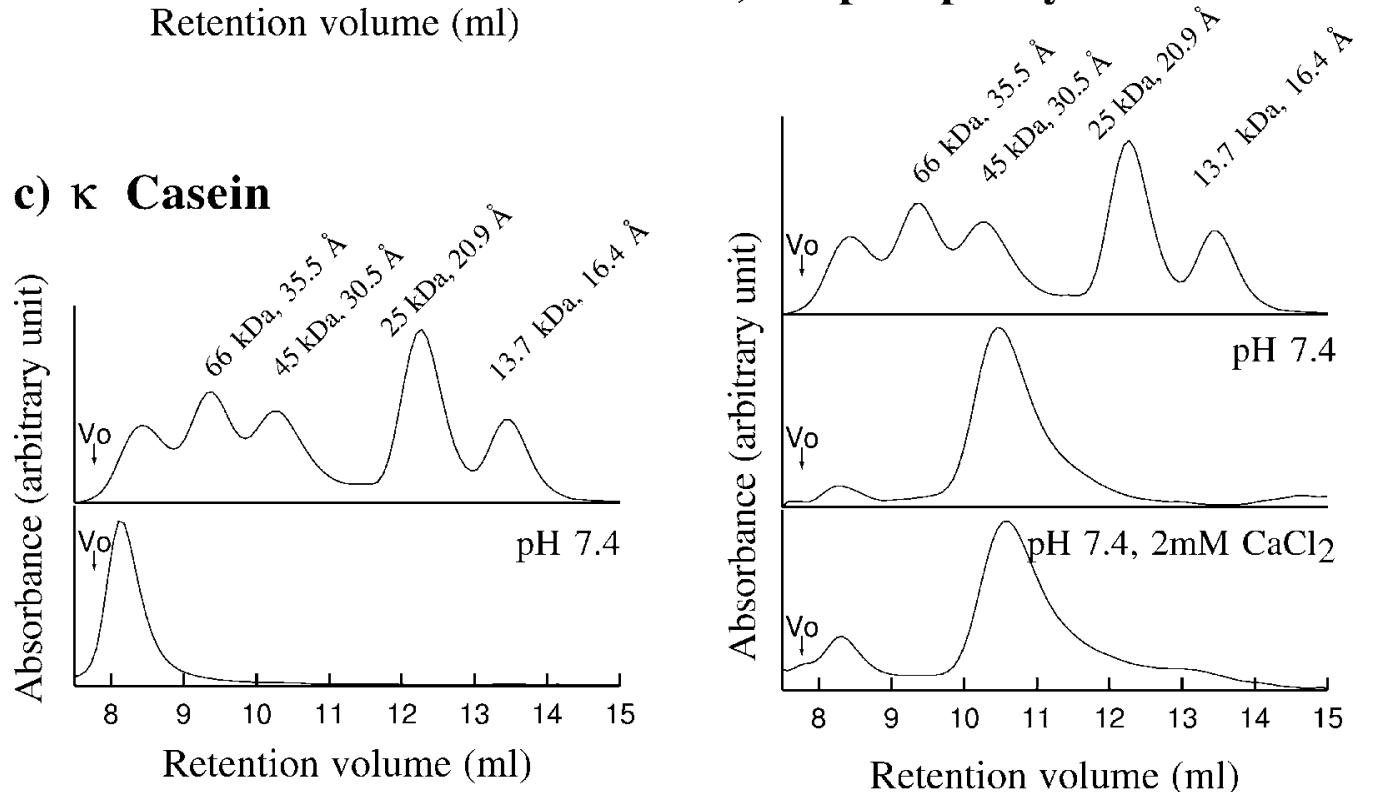

Retention volume $(\mathrm{ml})$

Figure 1. Oligomerization state of caseins. Analysis of purified caseins by gel filtration chromatography: (a) $\alpha_{\mathrm{s}}$-caseins; (b) $\beta$-casein; (c) $\kappa$ casein; (d) dephosphorylated $\alpha_{\mathrm{s}}$-caseins. Each protein was applied at a concentration of $0.1 \mathrm{mg} / \mathrm{ml}$ to a Superdex $75 \mathrm{HR} 10 / 30$ column preequilibrated with the buffer. The buffers used were: $10 \mathrm{~m} M$ Tris, $150 \mathrm{~m} M \mathrm{NaCl}, \mathrm{pH} 9.3$, at $25^{\circ} \mathrm{C} ; 10 \mathrm{~m} M \mathrm{HEPES}, 150 \mathrm{~m} M \mathrm{NaCl}, \mathrm{pH}$ 7.4, at $25^{\circ} \mathrm{C}$; $10 \mathrm{~m} M$ HEPES, $150 \mathrm{~m} M \mathrm{NaCl}, 2 \mathrm{~m} M \mathrm{CaCl}_{2}, \mathrm{pH} 7.4$, at $25^{\circ} \mathrm{C} ; 10 \mathrm{~m} M$ Na Acetate, $150 \mathrm{~m} M \mathrm{NaCl}, \mathrm{pH} 5.4$, at $25^{\circ} \mathrm{C} ; 10 \mathrm{~m} M$ Tris, $150 \mathrm{~m} M \mathrm{NaCl}, \mathrm{pH} 7.0$, at $4^{\circ} \mathrm{C}$. For each panel, the top chromatogram corresponds to the molecular weight standards (BSA, ovalbumin, chymotrypsinogen $\mathrm{A}$, and ribonuclease $\mathrm{A}$ ). 

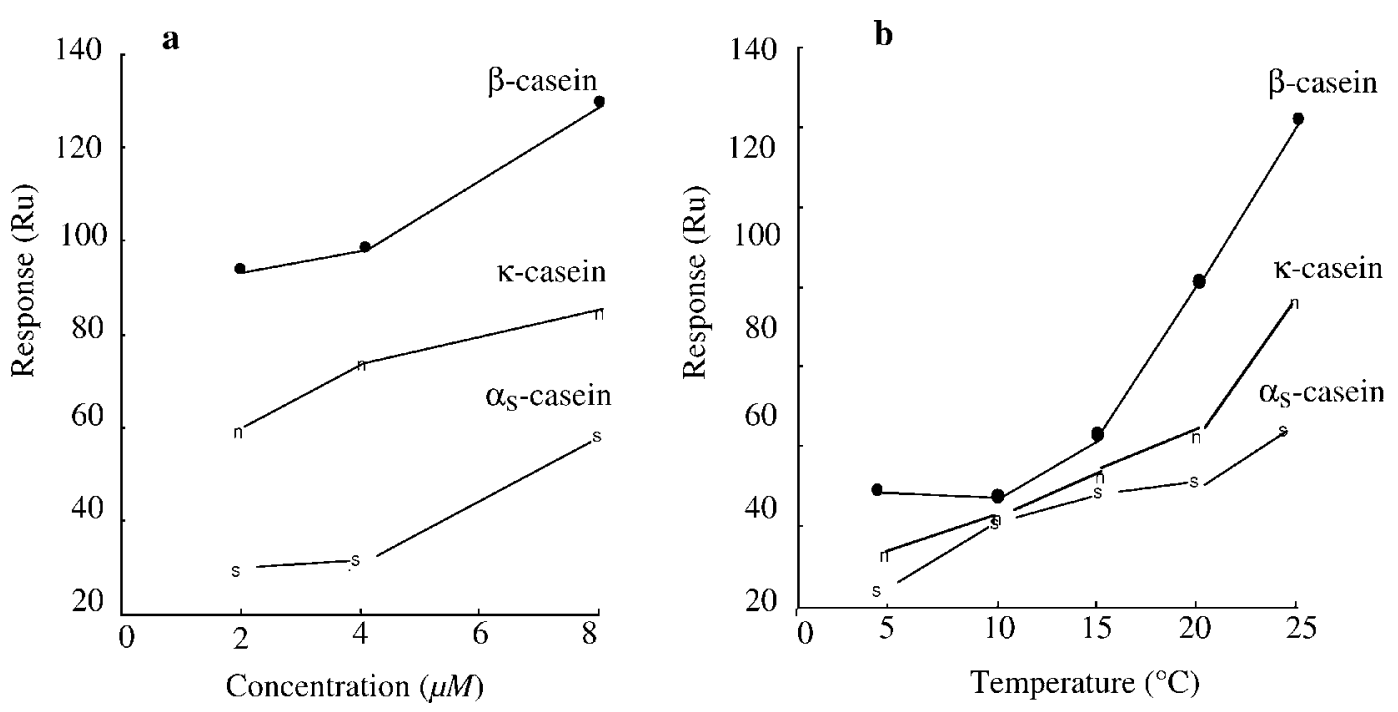

Figure 2. Binding response (Ru) of $\alpha_{\mathrm{s}^{-}}, \beta$-, and $\kappa$-caseins on an HPA sensor chip. (a) Effect of $\alpha_{\mathrm{s}^{-}}, \beta$-, and $\kappa$-casein concentrations on the binding response at $25^{\circ} \mathrm{C}$. (b) Effect of temperature on the binding response of $8 \mu M \alpha_{\mathrm{s}^{-}}$, $\beta$-, or $\kappa$-casein.

\section{Interaction of Caseins with an HPA Hydrophobic Surface: Determination of the Apparent Hydrophobicity}

We used a new method to compare the apparent hydrophobicity of $\alpha_{\mathrm{s}}$, $\beta$-, and $\kappa$-caseins. We determinated their binding level on the hydrophobic matrix of an HPA sensor chip using BIACORE. Because uncoated HPA chips are known to bind many proteins and especially bovine serum albumin (BSA; about $900 \mathrm{Ru}$ were recorded after injection of $50 \mu \mathrm{l}$ of $0.1 \mathrm{mg} / \mathrm{ml} \mathrm{BSA} \mathrm{on}$ the surface), we determined the minimal amount of detergent in the running buffer and in the sample buffer necessary to prevent BSA (taken as a test protein) adsorption. P20 (0.005\%) was sufficient to suppress BSA association (data not shown) but allowed a significant degree of hydrophobic binding (30 to $150 \mathrm{Ru}$ ) of the three groups of caseins (Figure $2 \mathrm{a}$ ); $\beta$-casein presented a higher binding level than $\kappa$-casein, which was itself higher than $\alpha_{\mathrm{s}}$-caseins at all concentrations tested. The SPR binding response as a function of temperature is reported in Figure $2 \mathrm{~b}$. At $10^{\circ} \mathrm{C}$, the Ru values of each casein were lower than at $25^{\circ} \mathrm{C}$ and not significantly different from each other. When the temperature rose above $20^{\circ} \mathrm{C}$, the differences in SPR responses between caseins increased with a maximal effect of temperature for $\beta$-casein.

\section{Interaction of Soluble Caseins with Immobilized Casein}

To study casein/casein interactions, each group of casein $\left(\alpha_{\mathrm{s}^{-}}, \beta\right.$-, and $\kappa$-casein) was immobilized by the $\varepsilon$ - amino group of their lysine residues on three different flowcells of a CM5 sensor chip, the fourth being used as a control. The immobilization level was the same $(2000 \mathrm{Ru})$ for each casein, indicating that the protein density on each test flowcell surface was the same. The interaction of each soluble injected casein with each immobilized casein was measured. The sensorgrams of $\alpha_{\mathrm{s}}$, $\beta$-, or $\kappa$-casein binding to the covalently-bound caseins, after subtraction of the appropriate controls, are shown in Figures 3a, b, and c. The soluble $\alpha_{\mathrm{s}^{-}}, \beta-$, and $\kappa$-caseins showed different binding responses on the three immobilized caseins: the $\alpha_{\mathrm{s}}$-casein binding levels (Figure 3a) were lower than the $\beta$-casein binding responses (Figure $3 \mathrm{~b}$ ) which themselves were lower than the $\kappa$-casein levels (Figure 3c). In Figure 3d, the same results are presented differently to compare the binding levels of each casein on the same immobilized casein. When $\alpha_{\mathrm{s}}$-caseins were immobilized, there was more $\kappa$-casein bound than $\beta$-casein (132 $\mathrm{Ru}$ vs $35 \mathrm{Ru}$ ) and more $\beta$-casein than $\alpha_{\mathrm{s}}$-caseins ( $35 \mathrm{Ru}$ vs $15 \mathrm{Ru}$ ). The same rank order was found for immobilized $\beta$ - and $\kappa$-caseins. These experiments also served to study the reversibility of the binding response: Nearly the same $\mathrm{Ru}$ level was obtained (Figure 3d) for the binding of $\alpha_{\mathrm{s}^{-}}$ caseins on $\beta$-casein $(30 \mathrm{Ru})$ as that of $\beta$-casein on $\alpha_{\mathrm{s}^{-}}$ caseins $(35 \mathrm{Ru})$, whereas the binding level of $\kappa$-casein on immobilized $\alpha_{\mathrm{s}}$-caseins (132 Ru) was superior to that of $\alpha_{\mathrm{s}}$-caseins on immobilized $\kappa$-casein $(26 \mathrm{Ru})$. This phenomenon was also observed for $\kappa$-casein on immobilized $\beta$-casein and is presumably due to the fact that $\kappa$-casein under these conditions was present as multimer in the flow (Figure 1c). Kinetic data and affinity constants 

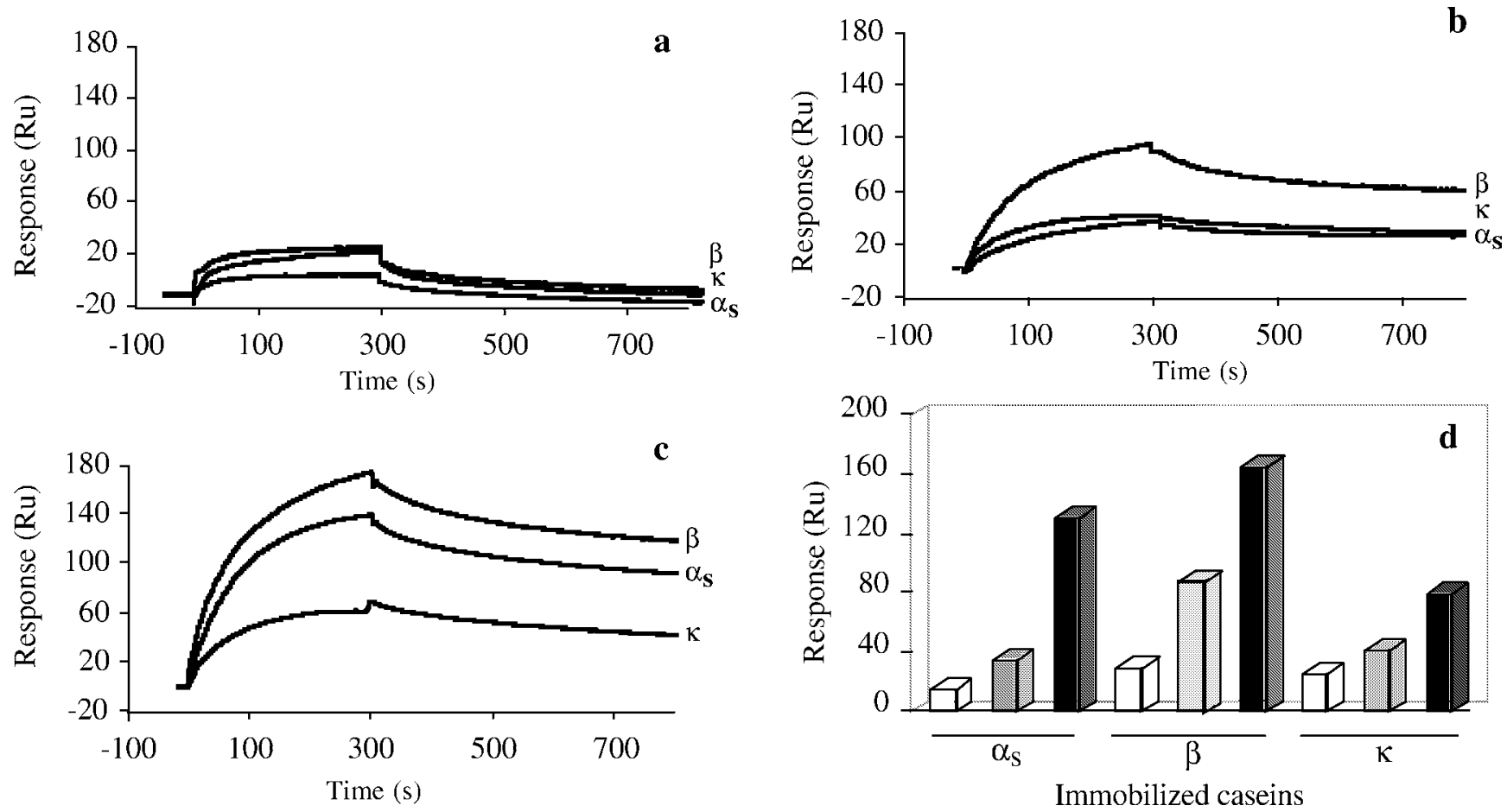

Figure 3. SPR analysis of the interaction between soluble caseins and caseins immobilized on a CM5 sensor chip at $25^{\circ} \mathrm{C}$. Buffer: 10 $\mathrm{m} M$ HEPES, pH 7.4, containing $150 \mathrm{~m} M$ NaCl. (a) Sensorgrams of soluble $\alpha_{\mathrm{s}^{-}}$-caseins binding to immobilized $\alpha_{\mathrm{s}^{-}}, \beta$-, and $\kappa$-caseins. (b) Sensorgrams of soluble $\beta$-casein binding to immobilized $\alpha_{\mathrm{s}^{-}}, \beta$-, and $\kappa$-caseins. (c) Sensorgrams of soluble $\kappa$-casein binding to immobilized $\alpha_{\mathrm{s}^{-}}, \beta$-, and $\kappa$-caseins. (d) Binding responses (Ru) at $25^{\circ} \mathrm{C}$ of soluble $\alpha_{\mathrm{s}^{-}}, \beta$-, and $\kappa$-caseins on immobilized $\alpha_{\mathrm{s}}^{-}, \beta-$, and $\kappa$-caseins on the CM5 sensor chip, $\alpha_{\mathrm{s}}$-caseins (white), $\beta$-casein (gray), $\kappa$-casein (black). Buffer: $10 \mathrm{~m} M$ HEPES pH 7.4, $150 \mathrm{~m} M \mathrm{NaCl}$.

were calculated only for $\alpha_{\mathrm{S}^{-}}$and $\beta$-caseins, which are essentially present as monomers in the flow (Figures 1a and b). These constants, calculated from sensorgrams a and $b$ (Figure 3) using a 1:1 Langmuir binding model are listed in Table 1. Globally, the $\mathrm{K}_{\mathrm{D}}$ values were in the same range $\left(10^{-7} M\right)$ : The greatest association rates were obtained for the binding of soluble $\alpha_{\mathrm{s}}$-casein, but this binding displayed also high dissociation rates. The binding levels $\left(\beta>\alpha_{\mathrm{s}}\right)$ were influenced more so by the dissociation rates than by the association rates. However, the difference in the rate constants when $\alpha_{\mathrm{s}}$-caseins (or $\beta$-casein) were tested in soluble form or coated onto the sensor chip may indicate that coupling of protein to the chip modifies in part its conformation and, therefore, its interaction with $\beta$-casein (or $\alpha_{\mathrm{s}}$-casein) partner.

To further investigate the nature of the interactions during casein-casein association in relation to casein charges, the effect of $\mathrm{pH}$ on the binding level of $\alpha_{\mathrm{s}}$ and $\beta$-caseins to immobilized $\alpha_{\mathrm{s}}, \beta$-, and $\kappa$-caseins was studied (Figure 4). Three $\mathrm{pH}$ values were chosen (namely, 7.4, 6.4, and 5.4) above the casein isoelectric point of $\mathrm{pH} 4.6$ to avoid precipitation. The results show that decreasing the $\mathrm{pH}$ increased the binding of $\alpha_{\mathrm{s}^{-}}$

Table 1. Kinetic data obtained by the sensorgrams of soluble $\alpha_{\mathrm{s}^{-}}$and $\beta$-caseins binding to immobilized $\alpha_{\mathrm{s}^{-}}, \beta$-, and $\kappa$-caseins. ${ }^{\mathrm{a}}$

\begin{tabular}{lllll}
\hline $\begin{array}{l}\text { Immobilized } \\
\text { casein }\end{array}$ & $\begin{array}{l}\text { Soluble } \\
\text { casein }\end{array}$ & $\mathrm{k}_{\mathrm{a}} \times 10^{-3}\left(M^{-1} \mathrm{~s}^{-1}\right)$ & $\mathrm{k}_{\mathrm{d}} \times 10^{3}\left(\mathrm{~s}^{-1}\right)$ & $\mathrm{K}_{\mathrm{D}} \times 10^{7}(M)$ \\
\hline$\alpha_{\mathrm{s}}$ & $\alpha_{\mathrm{s}}$ & $9.17 \pm 0.20$ & $4.61 \pm 0.03$ & $5.00 \pm 0.14$ \\
$\beta$ & $\beta$ & $1.62 \pm 0.04$ & $1.03 \pm 0.01$ & $6.36 \pm 0.22$ \\
& $\alpha_{\mathrm{s}}$ & $8.42 \pm 0.23$ & $1.96 \pm 0.02$ & $2.33 \pm 0.09$ \\
$\kappa$ & $\beta$ & $2.09 \pm 0.04$ & $1.20 \pm 0.01$ & $5.74 \pm 0.16$ \\
& $\alpha_{\mathrm{s}}$ & $8.92 \pm 0.16$ & $1.01 \pm 0.01$ & $1.12 \pm 0.03$ \\
& $\beta$ & $3.15 \pm 0.02$ & $0.67 \pm 0.01$ & $2.12 \pm 0.04$ \\
\hline
\end{tabular}

aThe values in this table were calculated from the sensorgrams in Figure 3. 


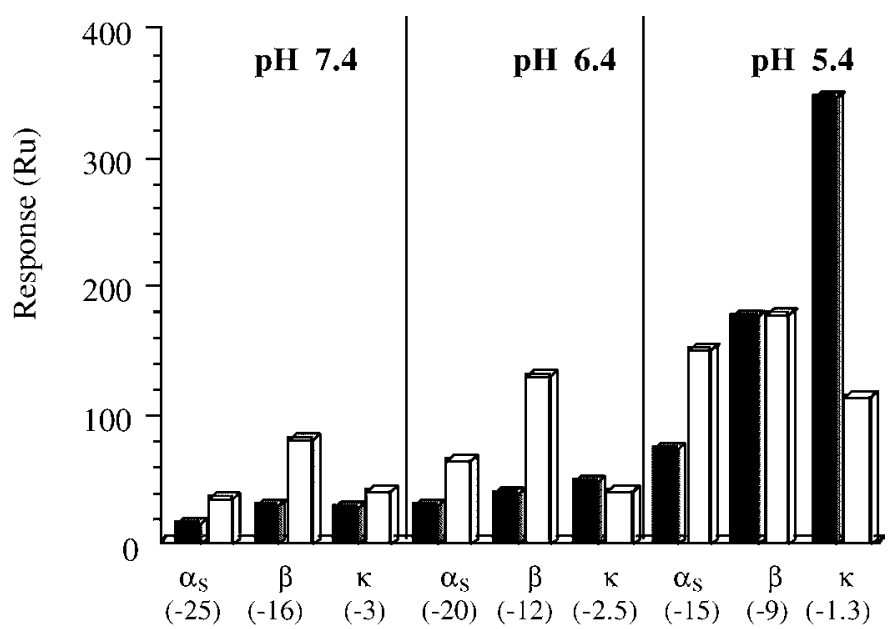

Immobilized caseins

Figure 4. Effect of $\mathrm{pH}$ on the binding responses $(\mathrm{Ru})$ of soluble $\alpha_{\mathrm{s}}$-caseins ( $\square$ ) and $\beta$-casein $(\square)$ on immobilized $\alpha_{\mathrm{s}^{-}}, \beta$ - and $\kappa$-caseins immobilized on the CM5 sensor chip. The calculated net charges of the caseins at the given $\mathrm{pH}$ values are presented in parentheses. The buffers used were $10 \mathrm{~m} M$ HEPES, $\mathrm{pH} 7.4 ; 10 \mathrm{~m} M$ HEPES, pH 6.4; $10 \mathrm{~m} M$ Acetate, $\mathrm{pH}$ 5.4; all buffers contained $150 \mathrm{mM}$ NaCl. HEPES and acetate buffers gave identical results at each $\mathrm{pH}$.

and $\beta$-casein on the three immobilized caseins, with a greater effect observed between $\mathrm{pH} 6.4$ and 5.4 (Figure 4). At $\mathrm{pH} 7.4$, the binding values were globally low and similar, whereas at $\mathrm{pH} 6.4$ and especially at $\mathrm{pH} 5.4$, the binding level of $\alpha_{\mathrm{s}}$-caseins on immobilized $\kappa$-casein was higher than on $\beta$-casein and $\alpha_{\mathrm{s}}$-caseins. These results can be correlated with the electronegative net charge of each casein calculated at the three $\mathrm{pH}$ values studied: $\alpha_{\mathrm{s}}$-caseins are more electronegative than $\beta$ casein, which are more electronegative than $\kappa$-casein; the decrease in $\mathrm{pH}$ decreased the global negative charge of the caseins. Between $\mathrm{pH} 6.4$ and 5.4, the $\mathrm{pH}$ effect on the binding levels obtained for soluble $\alpha_{\mathrm{s}}$-caseins was generally higher than for soluble $\beta$-casein, in accordance with their global negative charges (indicated in Figure 4 ). The $\beta$-casein binding levels were always higher on immobilized $\beta$-casein than on $\alpha_{\mathrm{s}^{-}}$and $\kappa$-caseins, whatever the $\mathrm{pH}$ value; this is probably due to a contributing hydrophobic effect.

The effect of calcium $(2 \mathrm{mM})$ on the binding of soluble $\alpha_{\mathrm{s}}$-caseins to immobilized $\alpha_{\mathrm{s}^{-}}, \beta$-, and $\kappa$-caseins at $\mathrm{pH}$ 7.4 (running and sample buffers contained $10 \mathrm{mM}$ HEPES, $150 \mathrm{~m} M \mathrm{NaCl}$ ) is shown in Figure 5. Only a small increase $(<35 \mathrm{Ru})$ in the $\alpha_{\mathrm{s}}$-caseins binding levels was observed in the presence of calcium (Figure 5); but no significant effect of calcium was observed for binding of the soluble $\beta$ - and $\kappa$-caseins (data not shown). Similar experiments were also carried out without $\mathrm{NaCl}$ in the running and sample buffers. The calcium effect on the

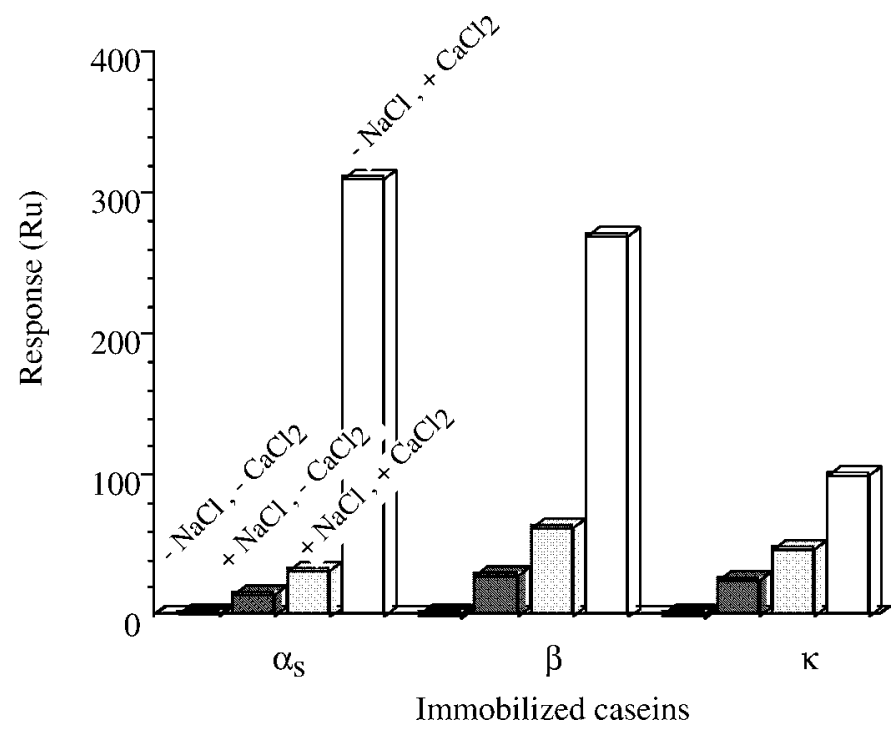

Figure 5. Effect of $\mathrm{CaCl}_{2}(2 \mathrm{mM})$ and $\mathrm{NaCl}(150 \mathrm{mM})$ on the binding response of soluble $\alpha_{\mathrm{s}}$-caseins on immobilized $\alpha_{\mathrm{s}}-, \beta$ - and $\kappa$ caseins on the CM5 sensor chip. Buffer: $10 \mathrm{~m} M$ HEPES, pH 7.4, without $\mathrm{NaCl}$ and without $\mathrm{CaCl}_{2}$ (black), with $\mathrm{NaCl}$ and without $\mathrm{CaCl}_{2}$ (dark gray), with $\mathrm{NaCl}$ and with $\mathrm{CaCl}_{2}$ (gray), without $\mathrm{NaCl}$ and with $\mathrm{CaCl}_{2}$ (white).

association was notably enhanced: the addition of calcium $(2 \mathrm{mM})$ in the absence of $\mathrm{NaCl}$ led to higher binding levels, whereas in the absence of calcium, the association level fell to zero. In the absence of $\mathrm{NaCl}$, calcium had a greater activating effect on the binding of $\alpha_{\mathrm{s}}$ caseins to immobilized $\alpha_{\mathrm{s}}$-caseins (309 Ru) than to immobilized $\beta$-casein $(271 \mathrm{Ru})$ or immobilized $\kappa$-casein (102 Ru; Figure 5). The same behavior was observed for soluble $\beta$-casein (data not shown). Since this activating effect seems to be correlated with the presence of phosphoseryl groups on casein molecules, we decided to determine the role of phosphoserine residues on casein interactions in the presence of calcium in the reaction medium. To this end, we compared the binding of dephosphorylated $\alpha_{\mathrm{s}}$-caseins and native $\alpha_{\mathrm{s}}$-caseins to immobilized $\alpha_{\mathrm{s}^{-}}, \beta$-, and $\kappa$-caseins in a HEPES buffer, $\mathrm{pH}$ 7.4, with $\mathrm{NaCl}(150 \mathrm{mM}$ ) but without calcium (Figure 6). Dephosphorylated $\alpha_{\mathrm{s}}$-caseins gave a greater association level than did native $\alpha_{\mathrm{s}}$-caseins, whereas the $\mathrm{K}_{\mathrm{D}}$ values were not significantly different (in the range of $10^{-7} \mathrm{M}$ ). In fact, dephosphorylation of $\alpha_{\mathrm{s}}$-caseins, which preserves the positive charge on the amino groups but abolishes the negative charges on the phosphoryl groups, led to a rise in the isoelectric point of the proteins with a decreased global negative charge. Comparatively, these experiments indicate that dephosphorylated $\alpha_{\mathrm{s}}$-caseins displayed an increased binding capacity which was greater for immobilized $\alpha_{\mathrm{s}}$-caseins (13fold) than for $\beta$-caseins ( 7 -fold) or $\kappa$-caseins ( 5 -fold). 


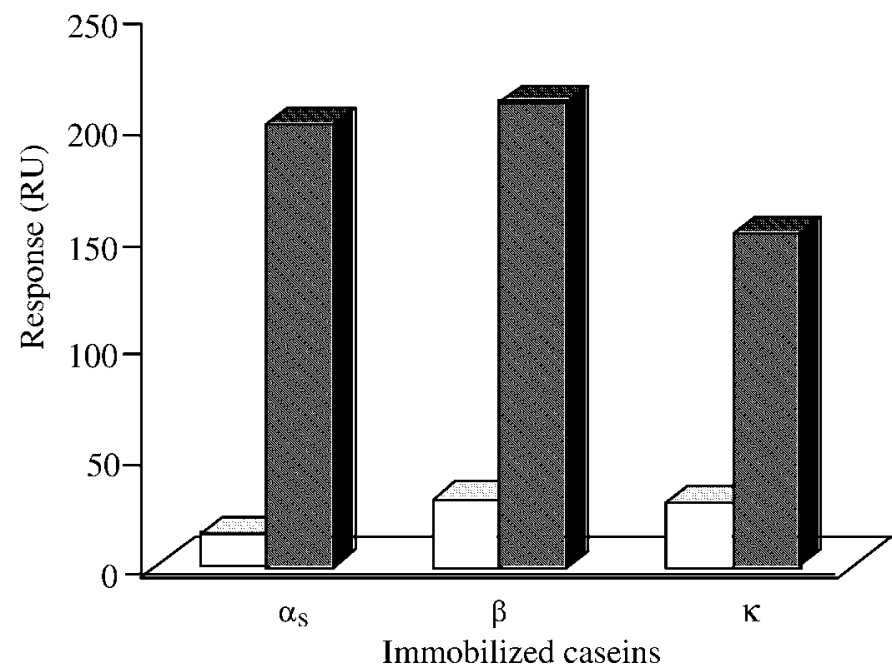

Figure 6. Binding response of soluble $\alpha_{\mathrm{s}}$-caseins $(\square)$ and dephosphorylated $\alpha_{\mathrm{s}}$-caseins ( $\left.\mathbf{\square}\right)$ on $\alpha_{\mathrm{s}^{-}}, \beta$ - and $\kappa$-caseins immobilized on the CM5 sensor chip. Buffer: $10 \mathrm{~m} M$ HEPES, pH 7.4, $150 \mathrm{~m} M \mathrm{NaCl}$.

Concerning the calcium effect in the absence of $\mathrm{NaCl}$, the sensorgrams obtained for $\alpha_{\mathrm{s}}$-caseins confirmed that calcium was necessary for measurable binding of $\alpha_{\mathrm{s}}$ caseins to immobilized $\alpha_{\mathrm{s}^{-}}, \beta$-, and $\kappa$-caseins (Figures $7 \mathrm{a}, \mathrm{b}$, and $\mathrm{c})$. In contrast, the binding of dephosphorylated $\alpha_{\mathrm{s}^{-}}$-caseins to $\alpha_{\mathrm{s}^{-}}$and $\beta$-caseins was independent of the presence of calcium (Figures $8 \mathrm{a}$ and $\mathrm{b}$ ). Only the binding of dephosphorylated $\alpha_{\mathrm{s}}$-caseins to $\kappa$-casein was enhanced in the presence of calcium (Figure 8c). The lack of a calcium effect on the binding of dephosphorylated $\alpha_{\mathrm{s}}$-caseins to immobilized $\alpha_{\mathrm{s}^{-}}$and $\beta$-caseins rules out the possibility of the formation of calcium bridges between a carboxyl group of dephosphorylated $\alpha_{\mathrm{s}}$-caseins and a phosphoryl or a carboxyl group of the $\alpha_{\mathrm{s}^{-}}$and $\beta$-caseins in this model at this calcium concentration.

\section{DISCUSSION}

The casein molecules have different degrees of hydrophobicity: $\alpha_{\mathrm{s}}$-caseins, although being the most hydrophilic, present hydrophobic C-terminal parts; $\beta$-casein has a predominantly hydrophobic neutral C-terminal region and a charged $\mathrm{N}$-terminal peptide; $\kappa$-casein, like $\beta$-casein but slightly more hydrophilic, presents a hydrophobic neutral $\mathrm{N}$-terminal region and a highly charged C-terminal peptide with only one phosphoseryl residue but several glycosylated sites (Swaisgood, 1992). It is important to quantify the hydrophobic potential of interaction between the different caseins in solution, because it is essential in the maintenance of micellar structure (Slattery et al., 1989) and represents the main driving forces involved in network formation during the enzymatic coagulation of milk (Bringe and
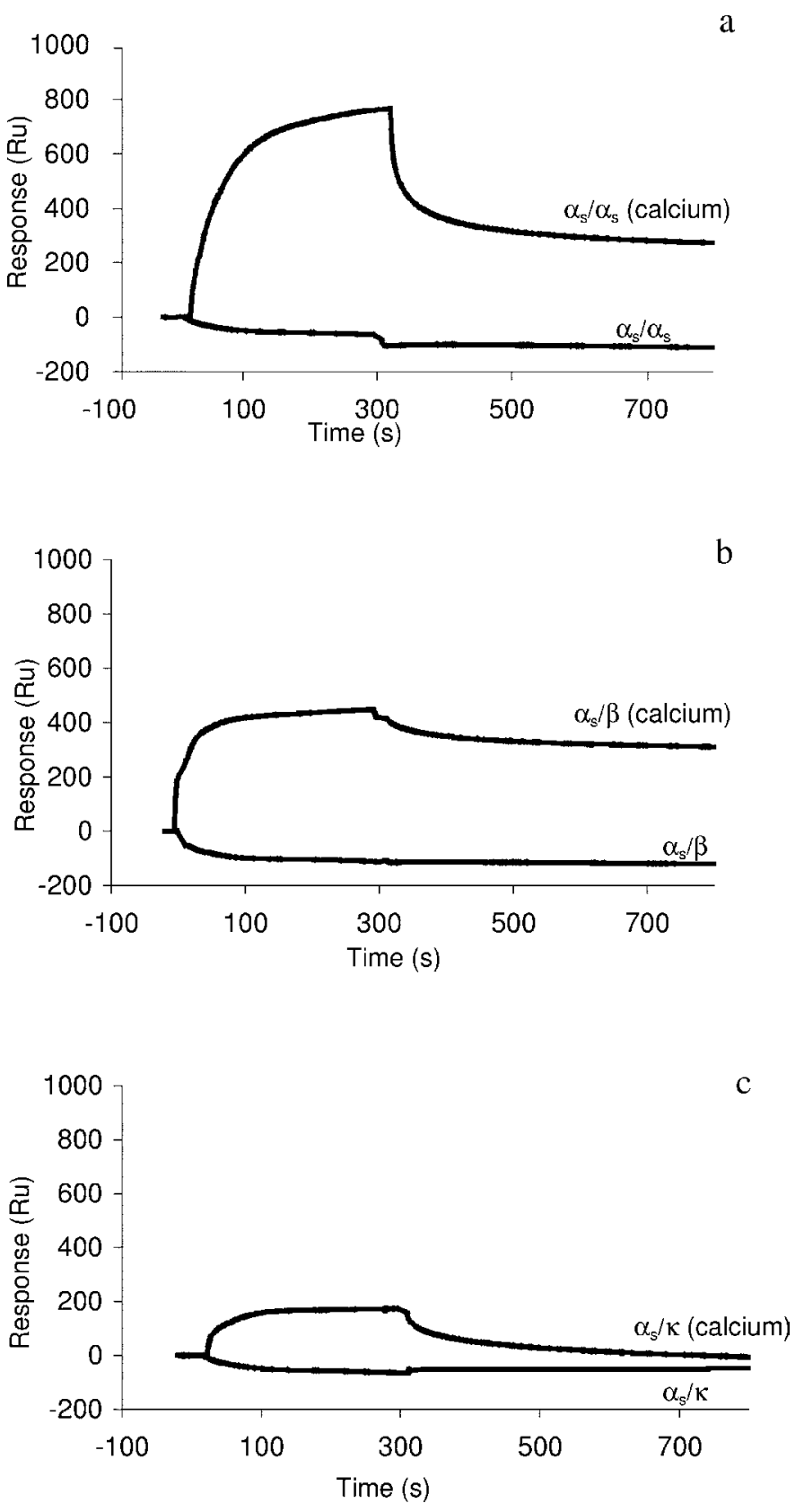

Figure 7. Effect of $2 \mathrm{mM} \mathrm{CaCl} 2$ on the interaction of soluble $\alpha_{\mathrm{s}}$ caseins with immobilized $\alpha_{\mathrm{s}}{ }^{-}, \beta$ - and $\kappa$-caseins on the CM5 sensor chip. Buffer: $150 \mathrm{~m} M$ HEPES, pH 7.4. (a) Sensorgrams of soluble $\alpha_{\mathrm{s}^{-}}$ caseins binding to immobilized $\alpha_{\mathrm{s}}$-caseins (a), to immobilized $\beta$-casein (b), and to immobilized $\kappa$-casein (c).

Kinsella, 1987). Usually, the apparent hydrophobicity of native proteins is determined by using a fluorescent probe such as 1, 8-anilinonaphthalenesulfonic acid (ANS; Hayakama and Nakai, 1985) or by using a detergent such as sodium dodecyl sulfate (Kato et al., 1984). In this work, our original approach consisted of measuring the interaction of different caseins on hydrophobic 

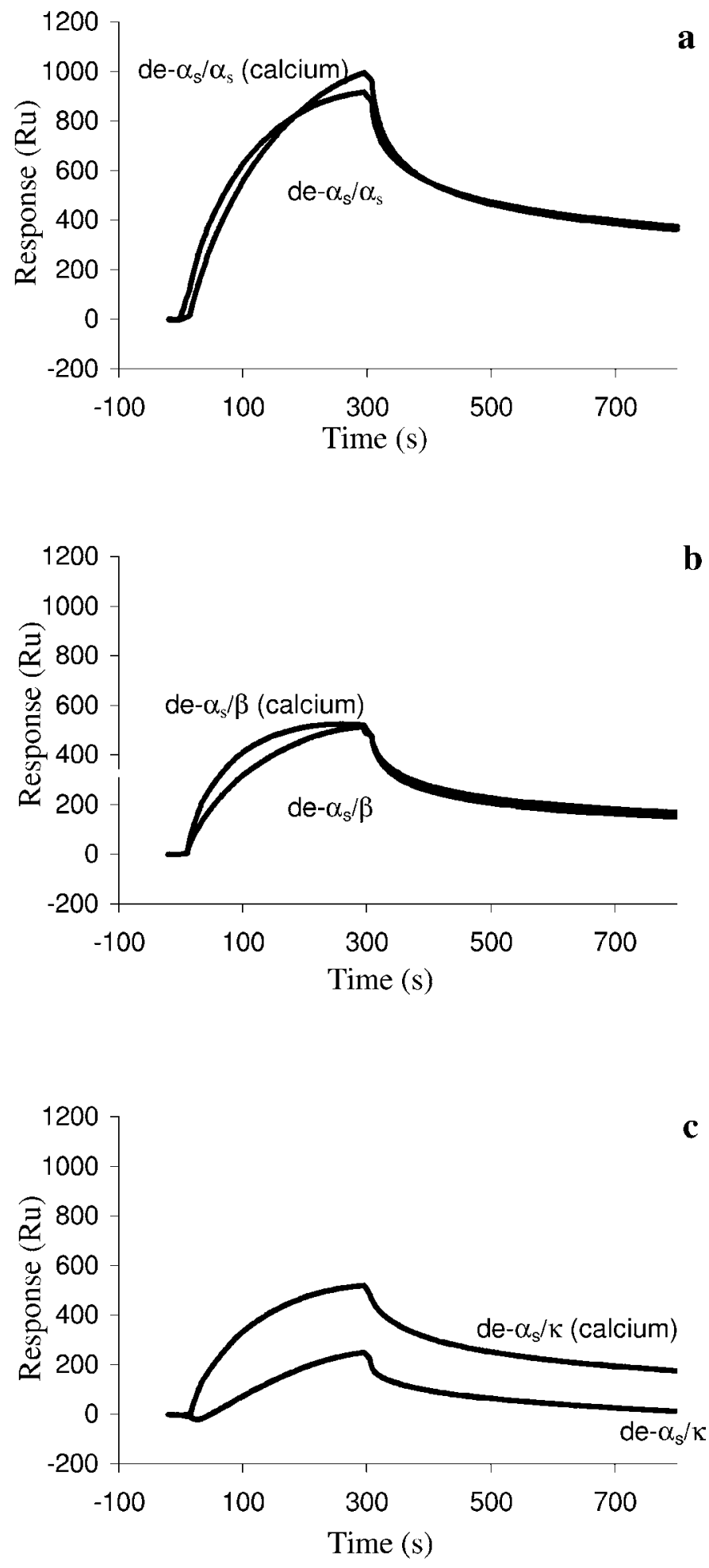

Figure 8. Effect of $2 \mathrm{mM} \mathrm{CaCl}{ }_{2}$ on the interaction of soluble dephosphorylated $\alpha_{\mathrm{s}}$-caseins $\left(\right.$ de- $\left.\alpha_{\mathrm{s}}\right)$ with immobilized $\alpha_{\mathrm{s}^{-}}, \beta$ - and $\kappa$ caseins on the CM5 sensor chip. Buffer: $150 \mathrm{~m} M$ HEPES, pH 7.4. Sensorgrams of soluble dephosphorylated $\alpha_{\mathrm{s}}$-caseins binding to immobilized $\alpha_{\mathrm{s}}$-caseins (a), to immobilized $\beta$-casein (b), and to immobilized $\kappa$-casein (c). surfaces in the presence of a nonionic polyoxyethylenesorbitan surfactant by using SPR technology.

The SPR binding levels obtained for each of the caseins were in good agreement with the range of hydrophobicity reported in the literature, i.e., 5.58, 5.12, 4.87, and $4.64 \mathrm{~kJ}$ per residue for $\beta-, \kappa_{-}, \alpha_{\mathrm{s} 1^{-}}$, and $\alpha_{\mathrm{s} 2^{-}}$casein, respectively, (Fox, 1989) and with the extent of apolar amino acids in the primary sequence of each casein, namely, 72/209 for $\beta$-casein (34.4\%), 54/169 for $\kappa$-casein (31.9\%), 63/199 for $\alpha_{\mathrm{s} 1}$-casein (31.6\%), and 58/207 for $\alpha_{\mathrm{s} 2}$-casein (28\%). Moreover, the SPR response on the hydrophobic matrix increased with increasing temperature, confirming the hydrophobic nature of these interactions. Since the SPR analysis on HPA sensor chips was conclusive enough to discriminate between $\alpha_{\mathrm{s}^{-}}$, $\beta$-, and $\kappa$-caseins, this technique might represent a new and simple procedure for a quantitative evaluation of apparent protein hydrophobicity in an aqueous environment.

Although hydrophobic interactions are important in casein/casein interactions, other forces such as electrostatic ones should also be taken into account. The differences in the sensorgrams of casein/casein interactions at neutral $\mathrm{pH}$ could be attributed, to a large extent, to charge differences. In fact, the sensorgrams in Figure 3 show that the highest SPR binding response at $\mathrm{pH}$ 7.4 was given by the least electronegative soluble casein $\left(\kappa\right.$-casein $>\beta$-casein $>\alpha_{\mathrm{s}}$-caseins). The high binding level observed for soluble $\kappa$-casein may be due in part to the multimeric state of soluble $\kappa$-casein. For the $\alpha_{\mathrm{s}}$ - and $\beta$ caseins, the increase of binding level was mainly related to the decrease in global negative charge and, thus, to the decrease in dissociation rates.

The decrease in $\mathrm{pH}$ to 5.4 probably led to neutralization of the numerous charged phosphoryl groups, enabling non-ionic interactions to occur, as shown by the greatly increased binding levels at acidic $\mathrm{pH}$. This effect could be explained by the fact that the pKa value of the charged phosphoryl groups of phosphoserine is around 6 (Baumy et al., 1989). We also demonstrated that the reduction of ionic strength inhibited casein/casein interactions at neutral $\mathrm{pH}$, showing that electrostatic repulsions were important at this $\mathrm{pH}$. The presence of 150 $\mathrm{m} M \mathrm{NaCl}$ slightly increased the casein/casein interactions, suggesting that the positive monovalent sodium ion at this concentration neutralized the negatively charged groups. This reduction in charge repulsions could favor nonionic forces. The replacement of $\mathrm{NaCl}$ by $2 \mathrm{mM} \mathrm{CaCl}{ }_{2}$ considerably increased the binding response. In fact, the divalent calcium ion acted not only as a neutralizing agent of negatively charged groups but also as a cross-linking agent between each casein. We observed that the attraction between $\alpha_{\mathrm{s}}$-caseins and either $\alpha_{\mathrm{s}^{-}}$or $\beta$-caseins was stronger than between the 
$\alpha_{\mathrm{s}}$-caseins and $\kappa$-casein. This could be explained by the fact that $\alpha_{\mathrm{s}^{-}}$and $\beta$-caseins, which possess a $\operatorname{Ser}(\mathrm{P})$ Ser(P)-Ser(P)-Glu-Glu cluster (Aoki et al., 1987; Baumy et al., 1989), present a site of high affinity for calcium ions; whereas $\kappa$-casein with only one $\operatorname{Ser}(\mathrm{P})$ residue, only presents a site of weak affinity.

The phosphoserine residues can also be neutralized by chemically converting them to serine residues. Dephosphorylation of $\alpha_{\mathrm{s}}$-caseins diminished the electrostatic repulsions at $\mathrm{pH} 7.4$ and greatly enhanced their binding to the immobilized caseins, particularly to the most phosphorylated proteins (the $\alpha_{\mathrm{s}^{-}}$and $\beta$-caseins). Chemical modification experiments showed that calcium participates directly in the formation of calcium bridges between the phosphate esters on casein molecules. Different authors (Byler and Farrel, 1989; Swaisgood, 1993) have proposed that the carboxyl groups of glutamic or aspartic acid could form calcium bridges between caseins within a micellar structure but at concentrations up to $2 \mathrm{mM}$. Without completely denying a role for the carboxyl groups, it seems that in our experimental molecular model the insertion of calcium $(2 \mathrm{mM})$ was principally located between the phosphate groups of $\alpha_{\mathrm{s}^{-}}$and $\beta$-caseins.

\section{CONCLUSIONS}

In this paper, we have demonstrated that the apparent hydrophobicities of caseins determined by a new approach using SPR technology with hydrophobic sensor chips are in good agreement with the results reported by others. Using this technology, we also characterized the casein-casein interactions at the molecular level and the factors influencing these interactions. The $\mathrm{K}_{\mathrm{D}}$ values obtained for all the casein-casein interactions studied were in the range of $10^{-7} M$. At neutral $\mathrm{pH}$, the highest SPR binding response on the immobilized caseins was obtained for the least electronegative soluble casein $\left(\kappa>\beta>\alpha_{\mathrm{s}}\right)$. The decrease in protein charge, induced either by acidification, an increase in ionic strength, or phosphorylation minimized the charge repulsion and increased globally the casein-casein interactions. In the presence of $2 \mathrm{mM} \mathrm{CaCl}$, casein-casein interactions were strong for the most phosphorylated caseins $\left(\alpha_{\mathrm{s}}\right.$ and $\left.\beta\right)$, which possess a $\operatorname{Ser}(\mathrm{P})$ cluster, the site of high affinity for the calcium ion. Experiments with dephosphorylated $\alpha_{\mathrm{s}}$-caseins seemed also to confirm the predominant affinity of calcium for the phosphate groups of the $\alpha_{\mathrm{s}^{-}}$and $\beta$-caseins.

\section{ACKNOWLEDGMENTS}

We are greatly indebted to Dr. Sharon. L. Salhi for editing the manuscript. This work was supported in part by a grant from the University of Montpellier II (France).

\section{REFERENCES}

Andrews, A. L., D. Atkinson, M. T. A. Evans, E. G. Finer, J. P. Green, M. C. Phillips, and R. N. Robertson. 1979. The conformation and aggregation of bovine $\beta$-casein A. I Molecular aspects of thermal aggregation. Biopolymers 18:1105-1121.

Aoki, T., N. Yamada, I. Tomita, Y. Kako, and T. Imamura. 1987. Caseins are cross-linked through their ester phosphate groups by colloidal calcium phosphate. Biochim. Biophys. Acta 911:238-243.

Baumy, J. J., P. Guenot, S. Sinbandhit, and G. Brulé. 1989. Study of calcium binding to phosphoserine residues of $\beta$-casein and its phosphopeptide (1-25) by ${ }^{31}$ P NMR. J. Dairy Res. 56:403-409.

Berry, G. P., and L. K. Creamer. 1975. The association of bovine $\beta$ casein. The importance of the C-terminal region. Biochemistry. 14:3542-3545.

Bringe, N. A., and J. E. Kinsella. 1987. Forces involved in the enzymatic and the acidic coagulation of casein micelles. Pages 159 194 in Development in Food Protein. B. J. F. Hudson, ed., Elsevier Applied Sciences, London, United Kingdom.

Buchheim, W., and D. G. Schmidt. 1979. On the size of monomers and polymers of $\beta$-casein. J. Dairy Res. 46:277-280.

Byler, D. M., and H. M. Farrel Jr. 1989. Infrared spectroscopic evidence for calcium ion interaction with carboxylate groups of casein. J. Dairy Sci. 72:1719-1723.

Davies, D. T., and A. J. R. Law. 1980. The content and composition of protein in creamery milks in southwest Scotland. J. Dairy Res. 47:83-90.

De Kruif, C. G. 1999. Casein micelle interactions. Int. Dairy J. 9:183-188.

Fox, P. F. 1989. The milk protein system. Pages 1-53 in Developments in Dairy Chemistry. P. F. Fox, ed., Elsevier Applied Sciences, London, United Kingdom.

Gaucheron, F., Y. Le Graet, E. Boyaval, and M. Piot. 1997. Binding of cations to casein molecules: importance of physicochemical conditions. Milchwissenschaft. 52:322-327.

Groves, M. L., H. J. Dower, and H. M. Farrell Jr. 1992. Reexamination of the polymeric distributions of bovine $\kappa$-casein. J. Protein Chem. 11:21-26.

Hayakama, S., and A. Nakai. 1985. Relationships of hydrophobicity and net charge to the solubility of milk and soy proteins. J. Food Sci. 50:486-491.

Horne, D. S. 1998. Casein interactions: casting light on the black boxes, the structure in dairy products. Int. Dairy J. 8:171-177.

Jönsson, U., L. Fägerstam, B. Ivarsson, B. Johnsson, R. Karlsson, K. Lundh, S. Löfäs, B. Persson, H. Roos, I. Rönnberg, S. Sjölander, E. Stenberg, R. Ståhlberg, C. Urbaniczky, H. Östlin, and M. Malmqvist. (1991). Real-time biospecific interaction analysis using surface plasmon resonance and a sensor chip technology. BioTechniques 11, 620-627.

Karlsson, R., and A. Fält. 1997. Experimental design for kinetic analysis of protein-protein interactions with surface plasmon resonance biosensors. J. Immunol. Methods 200:121-133.

Kato, A., T. Matsuda, N. Matsudomi, and K. Kobayashi. 1984. Determination of protein hydrophobicity using a sodium dodecyl sulfate binding method. J. Agric. Food Chem. 32:284-287.

Payens, T. A. J. 1966. Association of caseins and their possible relation to structure of casein micelle. J. Dairy Sci. 49:1317-1324.

Pharmacia Biosensor, AB. 1994. in BIAapplications Handbook. Biosensor, ed. Pharmacia Biosensor AB Uppsala, Sweden.

Rollema, H. S. 1992. Casein association and micelle formation. Pages 111-140 in Advanced Dairy Chemistry P. F. Fox, ed., Elsevier Science Publishers., Barking, United Kingdom.

Schmidt, D. G. 1970. The association of $\alpha_{\mathrm{s} 1}$-casein B at pH 6.6. Biochem. Biophys. Acta. 207:130-138.

Schmidt, D. G., and T. A. J. Payens. 1976. Micellar aspects of casein. Pages 165-229 in Surface and Colloid Science. Vol. 9. E. Matijevic, ed. John Wiley and Sons, New York, NY. 
Schmidt, D. G. 1982. Association of caseins and casein micelle structure. Pages 61-86 in Developments in Dairy Chemistry-1. P. F. Fox, ed., Elsevier Science Publishers, London, United Kingdom.

Slattery, C. W., S. M. Sood, and P. Chang. 1989. Hydrophobic interactions in human casein micelle formation: $\beta$-casein aggregation. J. Dairy Res. 56:427-433.

Snoeren, T. H. M., B. Van Markwij, and R. Van Montfort. 1980. Some physicochemical properties of bovine $\alpha_{\mathrm{s} 2}$-casein. Biochem. Biophys. Acta. 622:268-276.

Swaisgood, H. E., and S. N. Timasheff. 1968. Association of $\alpha_{\mathrm{s}}$-casein $\mathrm{C}$ in the alkaline $\mathrm{pH}$ range. Arch. Biochem. Biophys. 125:344-361.
Swaisgood, H. E. 1992. Chemistry of the caseins. Pages 63-110 in Advanced Dairy Chemistry-1: protein 2nd ed. Elsevier Applied Science, London, United Kingdom.

Swaisgood, H. E. 1993. Review and update of casein chemistry. J. Dairy Sci. 76:3054-3061.

Thurn, A., W. Burchard, and R. Niki. 1987. Structure of casein micelle. I. Small angle neutron scattering and light scattering from $\beta$ - and $\kappa$-casein. Colloids Polymer Sci. 265:653-666.

Walstra, P. 1990. On the stability of casein micelles. J. Dairy Sci. 73:1965-1977. 